\title{
Study on Chloride Ion Penetration Resistance of Rubberized Concrete Under Steady State Condition
}

\author{
Nurazuwa Md Noor ${ }^{1, a}$, Daisuke Yamamoto ${ }^{2}$, Hidenori Hamada ${ }^{2}$ and Yasutaka Sagawa ${ }^{2}$ \\ ${ }^{1}$ Jamilus Research Center, Universiti Tun Hussein Onn Malaysia, 86400 Parit Raja, Johor, Malaysia \\ ${ }^{2}$ Department of Civil and Structural Engineering, Kyushu University, Nishi-Ku, Fukuoka 819-0395, Japan
}

\begin{abstract}
Foamed concrete is a controlled low density ranging from $400 \mathrm{~kg} / \mathrm{m}^{3}$ to $1800 \mathrm{~kg} / \mathrm{m}^{3}$, and hence suitable for the construction of buildings and infrastructures. The uniqueness of foamed concrete is does not use aggregates in order to retain low density. Foamed concrete contains only cement, sand, water and foam agent. Therefore, the consumption of cement is higher in producing a good quality and strength of foamed concrete. Without the present of aggregates, the compressive strength of foamed concrete can only achieve as high as $15 \mathrm{MPa}$. Therefore, this study aims to introduce the pelletized coconut fibre aggregate to reduce the consumption of cement but able to enhance the compressive strength. In the experimental study, forty-five (45) cube samples of foamed concrete with density $1600 \mathrm{~kg} / \mathrm{m}^{3}$ were prepared with different volume fractions of pelletized coconut fibre aggregate. All cube samples were tested using the compression test to obtain compressive strength. The results showed that the compressive strength of foamed concrete containing 5\%,10\%,15\% and $20 \%$ of pelletized coconut fibre aggregate are $9.6 \mathrm{MPa}, 11.4 \mathrm{MPa}, 14.6 \mathrm{MPa}$ and $13.4 \mathrm{MPa}$ respectively. It is in fact higher than the controlled foamed concrete that only achieves $9 \mathrm{MPa}$. It is found that the pelletized coconut fibre aggregate indicates a good potential to enhance the compressive strength of foamed concrete.
\end{abstract}

\section{Introduction}

Concrete structure exposed to aggressive environment such as marine environment and structure exposed to cold weather has tendency to received high penetration of chloride ion into concrete pores which leads to the corrosion of steel reinforcement. Corroded steel reinforcement tends to distress the concrete and high cost of repair and maintenance are required to overcome this problems. In this research, chloride transportation characteristics into concrete was studied on concrete with crumb rubber, $\mathrm{CR}$ as a fine aggregate in order to provide good resistance against chloride ion penetration. Study on used tire in concrete namely rubberized concrete started in early 1990's both on strength characteristics and durability performance. With the increasing of population and traffic, the utilization of used tire is important to controlled negative impact to the environment. Thus, this research was conducted to study the effectiveness of crumb rubber as constituent for concrete in providing good resistance against chloride ion penetration.

\footnotetext{
${ }^{a}$ Corresponding author : nurazuwa@uthm.edu.my
} 


\section{Materials Preparation}

\subsection{Mix design}

The mix design was divided into three main group of water to cement ratio, w/c as shown in Table 1. Each group contains $\mathrm{CR}$ at $0 \%, 10 \%, 15 \%$ and $20 \%$ and it was added in the concrete as sand replacement by volume. SF was substituted in the mixture with $\mathrm{w} / \mathrm{c}=35 \%$ in order to study the effectiveness of mineral admixture on strength and chloride ion diffusion. Mixing process was done in the controlled temperature room at $20^{\circ} \mathrm{C}$. Coarse aggregate was firstly added in the mixer, followed by binder and sand. CR and sand were mixed sufficiently until all CR completely added. All these materials was dry mixed and after 30 seconds, water was added and mixing was continued for an about 90 seconds. Then, mixer was stopped to allow hand mixing to ensure all materials in the mixer were homogeneously mixed. Mixing was finally continued for 60 seconds and stop, which makes total mixing time, became 3 minutes.

Table 1. Mix proportion of rubberized concrete.

\begin{tabular}{|c|c|c|c|c|c|c|c|c|c|c|c|c|c|}
\hline \multirow{3}{*}{ Group } & \multirow[b]{2}{*}{$\mathrm{CR} /(\mathrm{S}+\mathrm{CR})$} & \multirow[b]{2}{*}{$\mathrm{SF} / \mathrm{C}$} & \multirow{3}{*}{$w / c$} & \multirow{2}{*}{$\begin{array}{c}\text { Water } \\
\text { W }\end{array}$} & \multirow{2}{*}{$\begin{array}{c}\text { Cement } \\
\text { C }\end{array}$} & \multirow{2}{*}{$\begin{array}{l}\text { Silica } \\
\text { Fume } \\
\text { SF }\end{array}$} & Sand & $\begin{array}{l}\text { Crumb } \\
\text { Rubber }\end{array}$ & \multicolumn{2}{|c|}{$\begin{array}{c}\text { Coarse } \\
\text { Aggregates }\end{array}$} & \multicolumn{3}{|c|}{ Chemical Admixture } \\
\hline & & & & & & & S & CR & G1 & G2 & $\begin{array}{c}\text { Ether-based } \\
\text { polycarboxylate } \\
\text { superplasticizers }\end{array}$ & $\begin{array}{c}\text { Air- } \\
\text { entrained } \\
\text { agent }\end{array}$ & $\begin{array}{c}\text { Air- } \\
\text { modifying } \\
\text { agent }\end{array}$ \\
\hline & (Vol \%) & $(\%)$ & & & & & $\mathrm{kg} / \mathrm{m}^{3}$ & & & & $\%$ & $\%$ & $\%$ \\
\hline Control & 0 & 0 & 0.50 & 165 & 330 & 0 & 790 & 0 & 636 & 329 & 0.5 & 0.8 & \\
\hline 10CR-OSF & 10 & & & & & & 711 & 35 & & & 0.5 & 0.8 & \\
\hline 15CR-0SF & 15 & & & & & & 671 & 53 & & & 0.5 & 0.8 & \\
\hline Control & 0 & 0 & 0.35 & 160 & 457 & 0 & 741 & 0 & 608 & 405 & 0.5 & 0.8 & \\
\hline 10CR-0SF & 10 & & & & & & 667 & 34 & & & 0.5 & 0.8 & \\
\hline 15CR-0SF & 15 & & & & & & 629 & 50 & & & 0.7 & 0.8 & \\
\hline 20CR-0SF & 20 & & & & & & 594 & 67 & & & 0.7 & 0.7 & \\
\hline 10CR-10SF & 10 & 10 & 0.35 & 160 & 457 & 46 & 613 & 34 & 608 & 405 & 0.7 & & 1.5 \\
\hline 15CR-10SF & 15 & & & & & & 575 & 50 & & & 0.7 & & 2.2 \\
\hline 20CR-10SF & 20 & & & & & & 540 & 67 & & & 0.7 & & 2.8 \\
\hline
\end{tabular}

\subsection{Steady state condition}

Steady state condition is a process where chloride ion is allowed to migrate constantly into the pore solution of concrete under $15 \mathrm{~V}$ voltage [2]. Figure 1 shows the migration cell in order to measure chloride, $\mathrm{Cl}^{-}$ion that migrate from cathode towards anode and it achieved steady state condition when increment rate of $\mathrm{Cl}^{-}$in anode side becomes constant in time as described in Figure 2. The starting sodium hydroxide, $\mathrm{NaOH}$ solution in the anode side is $0.5 \mathrm{~mol} / \mathrm{L}$ and $0.3 \mathrm{~mol} / \mathrm{L}$ of sodium chloride, $\mathrm{NaCl}$ in the cathode side. Along the testing process, the chloride ion concentration in the anode shall be less than $0.05 \mathrm{~mol} / 1$, meanwhile as for cathode; the chloride ion concentration shall be more than $0.45 \mathrm{~mol} / 1$. Solution was completely renewed if any side of anode or cathode solution did not meet this limitation. Test was carried out on $\varnothing 100 \times 50 \mathrm{~mm}$ thickness rubberized concrete, cut from cylindrical concrete of size $\varnothing 100 \times 200 \mathrm{~mm}$ length. 


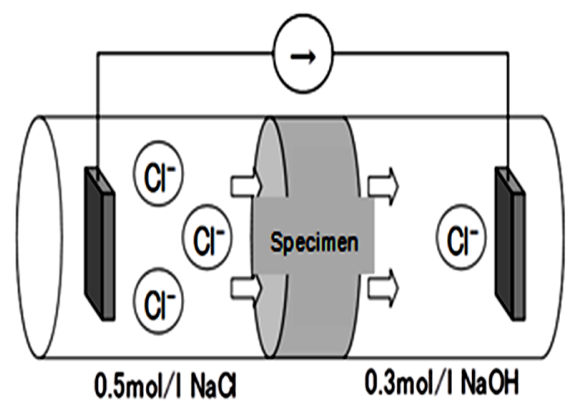

(b) Schematic diagram

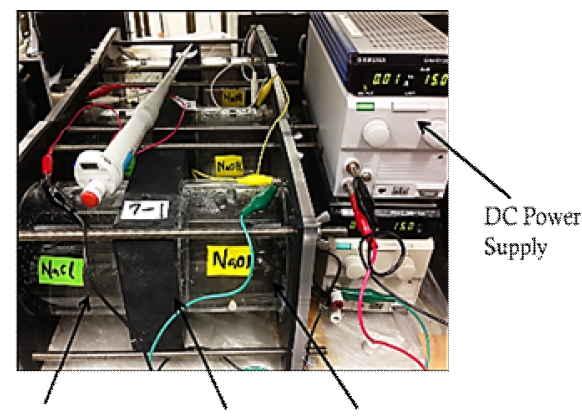

(a) Experimental setup

Figure 1. Migration cell.

Samples from the solution was taken to determine effective diffusion coefficient, $\mathrm{D}_{\mathrm{e}}$ by using NernstPlanck equation,

$$
D_{e}=\frac{J_{C l} R T L}{\left|Z_{c l}\right| F C\left(\Delta E-\Delta E_{C}\right)} \cdot 100
$$

where, $D_{e}$ is effective diffusion coefficient in $\mathrm{cm}^{2} /$ year, $R$ is gas constant $=8.31 \mathrm{~J} / \mathrm{mol} \mathrm{K}$, T is absolute temperature in $\mathrm{K}$ units, $\mathrm{Z}_{\mathrm{Cl}}$ is charge of chloride ion $=-1, \mathrm{~F}$ is the Faraday constant $=96,500 \mathrm{C} / \mathrm{mol}$, $\mathrm{C}_{\mathrm{Cl}}$ is measured chloride ion concentration in cathode side in mol/l, $\Delta \mathrm{E}-\Delta \mathrm{E}_{\mathrm{c}}$ is electrical potential difference between specimen surfaces in $\mathrm{V}$ and $\mathrm{L}$ is specimen length in $\mathrm{mm}$.

\section{Results and Discussion}

Results of $D_{e}$ are shown in Figure 2 to Figure 5. It was clearly seen that when CR is added in all mixture, resistance against chloride ion migration into the pore solution of concrete was improved. Even though, the effect in each group was slightly reduce due to small amount of CR replacement by volume, but the ability of CR in improving chloride transport characteristics cannot be neglected.

More than $50 \%$ of $\mathrm{D}_{\mathrm{e}}$ reduction was observed in $\mathrm{w} / \mathrm{c}=0.50$ when $10 \% \mathrm{CR}$ was added compared to control mixture as shown in Figure 3. When w/c was reduced from $50 \%$ to $35 \%$, the resistance against chloride penetration was much improved from $1.538 \mathrm{~cm}^{2} /$ year to $0.434 \mathrm{~cm}^{2} /$ year due to the increasing of binder in concrete that leads to dense concrete. The $\mathrm{D}_{\mathrm{e}}$ in $35 \% \mathrm{w} / \mathrm{c}$ mix kept decreasing slightly with the increasing of CR as shown in Figure 4.

The highest resistance was observed when $10 \%$ SF was used as additional binder and the reduction was about $60 \%$ to $65 \%$ in comparison to control mix as shown in Figure 5 . The ultrafine particles of SF allowed voids between cement particles and aggregate to be filled by SF [3]. This led to the porosity reduction and provides denser concrete. In addition, results on compressive strength were presented together with the $\mathrm{D}_{\mathrm{e}}$ and according to the literature, relationship between chloride ion migration through pore solution of concrete and compressive strength is linked to the pore structure of the rubberized concrete [4]. From this relationship, it indicates that the pore structure of the rubberized concrete was still under accepted level; where positive improvement in chloride ion transport was observed even though compressive strength was reduced. 


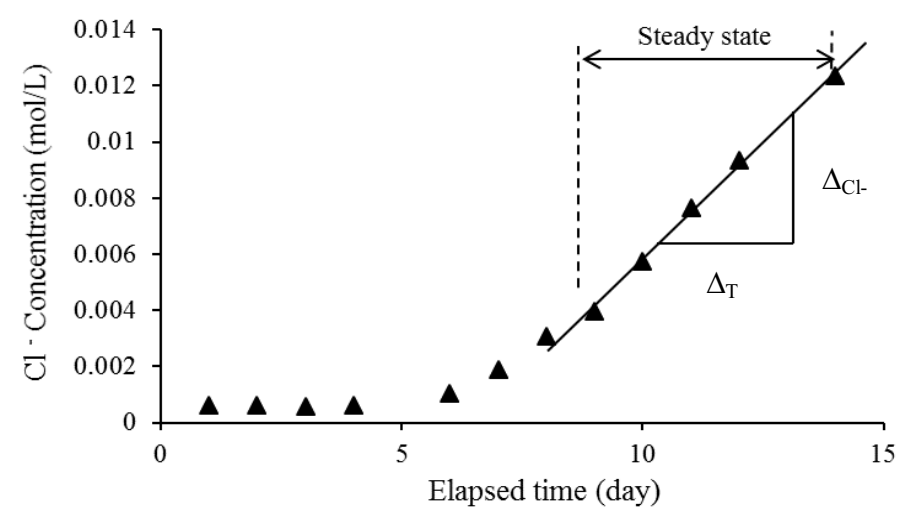

Figure 2. Steady state condition of chloride ion migration test.

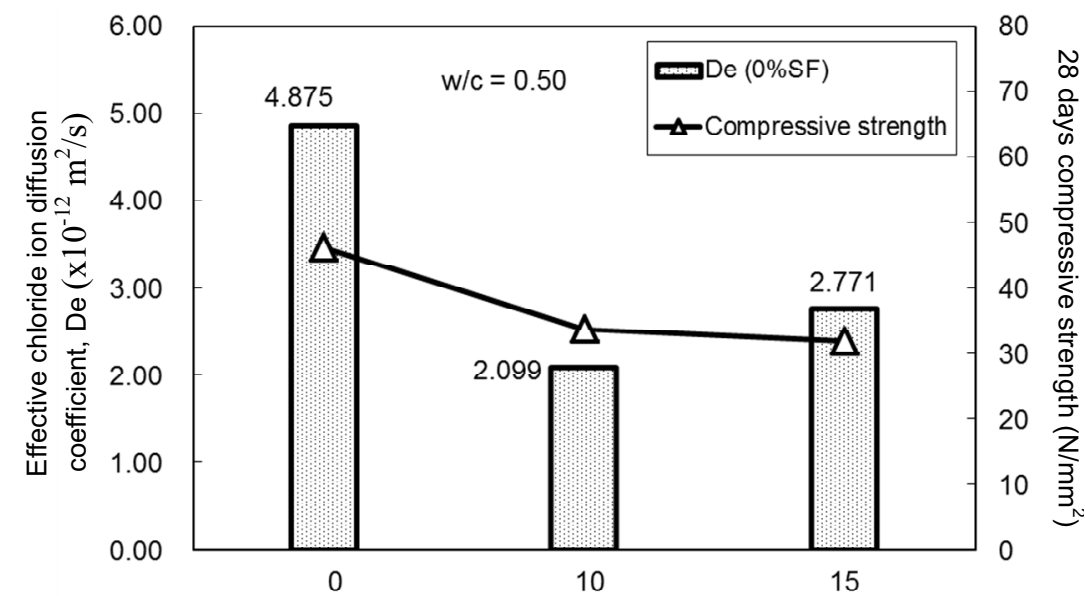

Figure 3. Effective diffusion coefficient and 28 days compressive strength of rubberized concrete with $\mathrm{w} / \mathrm{c}=0.50$ (without SF).

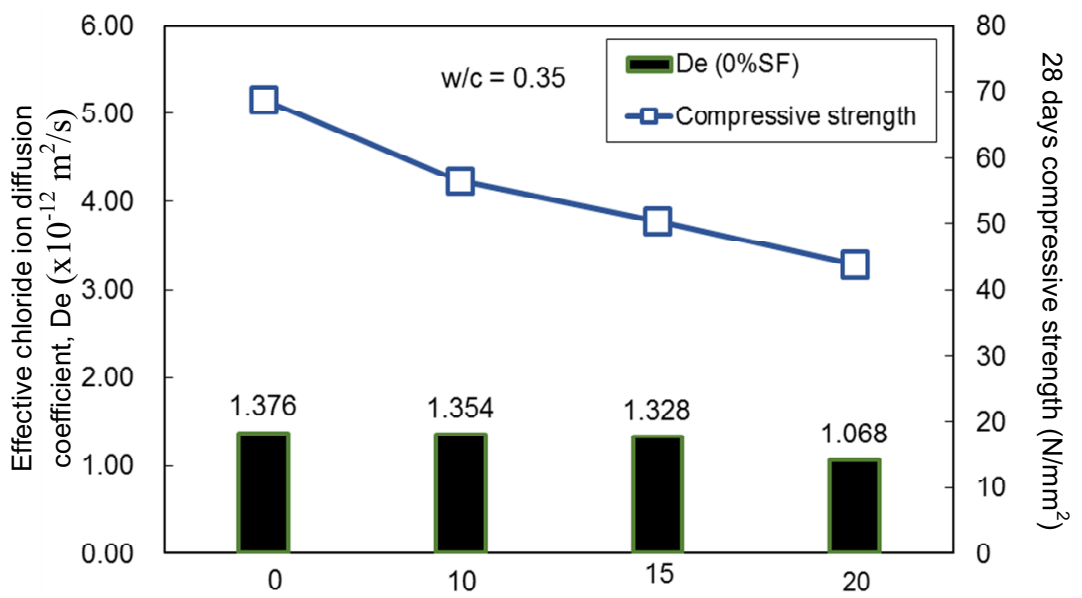

Figure 4. Effective diffusion coefficient and 28 days compressive strength of rubberized concrete with w/c $=0.35$ (without SF). 


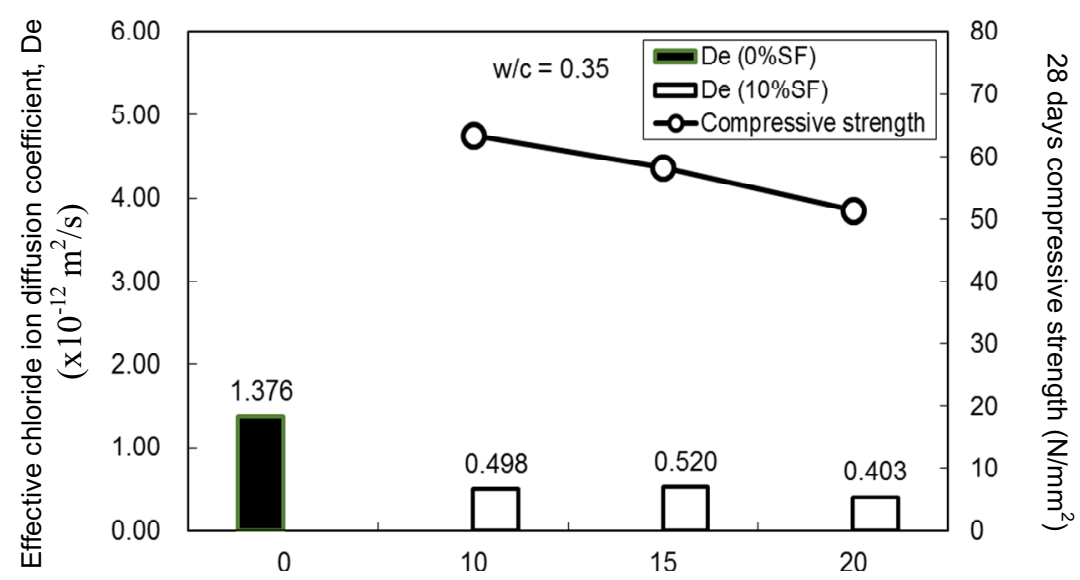

Figure 5. Effective diffusion coefficient and 28 days compressive strength of rubberized concrete with $\mathrm{w} / \mathrm{c}=0.35$ (with $10 \% \mathrm{SF}$ ).

\section{Conclusions}

Several conclusions can be drawn from this research as follows,

i) Effect of the $\mathrm{CR}$ in rubberized concrete was clearly seen in $\mathrm{w} / \mathrm{c}=0.50$ and mix with $\mathrm{SF}$ in $\mathrm{w} / \mathrm{c}=0.35$.

ii) Chloride transport characteristics were improved by increasing amount of CR due to the fact that CR has the ability to repel water.

iii) Resistance of rubberized concrete against chloride ion was much improved when $10 \% \mathrm{SF}$ was added as a binder.

iv) It was observed that compressive strength was reduce to $43 \%$ in $20 \%$ CR replacement without SF but it increasing slightly with the present of SF.

\section{Acknowledgement}

Special thanks to Hikari World Company Limited for their support in supplying the crumb rubber. Grateful acknowledgement was also dedicated to Malaysian Ministry of Higher Education in providing financial support to the first author.

\section{References}

[1] M.N. Nurazuwa, H. Hamada, Y. Sagawa and D. Yamamoto, Strength charactersitics of mortar mixed with tire crumb rubber as fine aggregates, Proceeding of $67^{\text {th }}$ Conference of Cement Technology, (2013).

[2] JSCE-G571-2003, Test method for effective diffusion coefficient of chloride ion in concrete by migration, JSCE Guidelines for Concrete No. 2, (2004).

[3] M. Gesoğlu and E. Güneyisi, Strength development and chloride penetration in rubberized concretes with and without Silica Fume, Materials and Structures, 40, 953-964, (2007).

[4] Cement Concrete and Aggregates, Chloride Resistance of Concrete, Australia, (2009).

[5] G.S. Kumaran, M. Nurdin and M. Lakshmipathy, A review on construction technologies that enables environmental protection: rubberized concrete, AJEAS1, 1, 41-45, (2008). 